\title{
Ciliary and mucus-net filter feeding, with special reference to fluid mechanical characteristics
}

\author{
C. Barker Jørgensen ${ }^{1}$, Thomas Kiørboe ${ }^{2}$, Flemming Møhlenberg ${ }^{3}$ and H. U. Riisgård ${ }^{4}$ \\ 'Zoophysiological Laboratory A, August Krogh Institute, Universitetsparken 13, DK-2100 Copenhagen $\varnothing$, Denmark \\ ${ }^{2}$ Danish Institute for Fisheries and Marine Research, Charlottenlund Slot, DK-2920 Charlottenlund, Denmark \\ ${ }^{3}$ Institute of Biology, Roskilde University Center, P.O. Box 260, DK-4000 Roskilde, Denmark \\ ${ }^{4}$ Marine Pollution Laboratory, National Agency of Environmental Protection, Kavalergården 6, DK-2920 Charlottenlund, \\ Denmark
}

\begin{abstract}
Filter characteristics have been deternined and compared in ciliary and mucus-net filter feeders. The ciliary feeders include the polychaete Sabella penicillus, the brachiopod Terebratulina retuso, the marine bivalves Monia squama, Cardium glaucum, and Petricola pholadiformis, and the freshwater bivalves Dreissena polymorpha, Unio pictarum, and Anodonta cygnea. The mucus-net feeders are the polychaete Chaetopterus variopedatus, the gastropod Crepidula fornicata, and the ascidians Styela clava, Ciona intestinalis, Ascidia virginia, Ascidia obliqua, and Ascidia mentula. Efficiencies of particle retention as a function of particle size was determined by counting of particles in samples of inhalant and exhalant water. The lower threshold for efficient particle retention varied from about $6 \mu \mathrm{m}$ in $T$. retuso to about $1 \mu \mathrm{m}$ in $D$. polymorpha. Mucus nets efficiently retained particles down to 1 to $2 \mu \mathrm{m}$. Filter feeding is characterized by processing of water at low pressures $\left(\leq 1 \mathrm{~mm} \mathrm{H}_{2} \mathrm{O}\right.$ ). Mechanisms of water processing and particle retention in brachiopods and bivalves are compared. It is concluded that laminar flow of through-currents and surface-currents in brachiopods is consistent with the hypothesis of capture of suspended particles by means of viscous forces acting upon the particles in the zone of contact between the 2 flow systems.
\end{abstract}

\section{INTRODUCTION}

Most suspension feeders feed by means of cilia, generally arranged in bands or tracts. Invertebrates feeding by means of cilia are traditionally classified as ciliary-mucoid feeders, implying that mucus plays an essential role in the feeding mechanisms. This role of mucus has, however, not been confirmed in representatives of several types of ciliary feeders, including sabellid polychaetes (Lewis, 1968; Bonar, 1972), brachiopods (Chuang, 1956; Rudwick, 1970; Strathmann, 1973) and bivalves (Jørgensen, 1981b; Kiørboe and Møhlenberg, 1981). In other groups of ciliary feeders there is good evidence that mucus secretion is basic to normal feeding: many gastropods (e.g. Crepidula fornicata) and ascidians generally. In these groups mucus is secreted to form nets through which the ciliary currents are filtered.

While an abundant literature deals with mechanisms by which the various types of suspension feeders process ambient water and retain suspended particles, until recently this literature has largely ignored that the flow of water and the movements of particles in the feeding structures are dominated by viscous forces characterized by low Reynolds numbers (Strathmann, 1971; Fenchel, 1980; Koehl and Strickler, 1981; Jørgensen, 1983). Understanding of the filtering processes requires knowledge of the efficiency by which the filters retain suspended particles, the velocity at which water passes through the filters, as well as the pressure heads generated by the water-transporting structures. The present paper contributes to this knowledge in representatives of various types of filter feeders.

\section{MATERIAL AND METHODS}

Experiments were conducted at various laboratories between June 1978 and December 1982.

The bivalves Cardium glaucum and Petricola pholadiformis were collected (June 1978) in the Limfjord (Denmark) and transferred to the seawater system 
$\left(17^{\circ} \mathrm{C}, 28 \% \mathrm{~S}\right)$ of the nearby Biological Station at Rønbjerg. Prior to experiments these infauna bivalves were allowed to bury themselves in beakers with sediment.

Experiments with the brachiopod Terebratulina retuso, the bivalve Monia squama and the polychaete Sabella penicillus were conducted at the Tjärnö Marine Biological Laboratory (Sweden) in July 1982. As these species (especially $T$. retuso and $M$. squama) require very long acclimation periods, animals from the exhibition aquaria of the laboratory were selected for experiments. These animals had been collected in the Koster Fjord (Sweden) and were acclimated to the laboratory's seawater system $\left(16^{\circ} \mathrm{C}, 33 \% \mathrm{~S}\right)$ during at least half a year. The animals were not removed from their original substratum during experiments.

The ascidians Ascidia virginia, A. obliqua, A. mentula, Ciona intestinalis and the polychaete Chaetopterus variopedatus were studied at Tjärnö in October 1982. The ascidians, originating from the Koster Fjord, were again selected from exhibition aquaria, whereas C. variopedatus were collected by divers in the Gulmar Fjord (Sweden) and transported to the Tjärnö laboratory. Measurements were made at $15^{\circ} \mathrm{C}$. Additional experiments with $C$. variopedatus from the Gulmar Fjord were carried out in the seawater system of the Marine Pollution Laboratory, Charlottenlund, $15^{\circ} \mathrm{C}$, $30 \%$ S) during October and November 1982. The ascidian Styela clava and the gastropod Crepidula fornicata, collected in western Limfjord, were also studied in Charlottenlund.

The freshwater bivalves Dreissena polymorpha, Unio pictarum and Anodonta cygnea were collected (August 1982) in Lake Bastrup, Zealand (Denmark), and transported to the nearby laboratory at Roskilde University Center. The bivalves were established in aquaria with water from Lake Bastrup. The epifaunal D. polymorpha were allowed to attach by their byssus on glass dishes and the 2 infauna species were allowed to bury themselves in beakers with sediment. Experiments were carried out at $10^{\circ} \mathrm{C}$.

Prior to and during experiments the animals were fed mixtures of algal cultures. In the experiments with the marine species suspensions were prepared of the following spherical algae (grown in axenic cultures): Nanochloris atomus (2 to $3 \mu \mathrm{m}$ ), Monochrysis lutheri (3 to $4 \mu \mathrm{m}$ ), Isochrysis galbana ( 4 to $5 \mu \mathrm{m})$, Dunaliella marina ( 5 to $7 \mu \mathrm{m}$ ). Tetraselmis suecica ( 6 to $8 \mu \mathrm{m}$ ) and the ovoid Rhodomonas sp. $(7 \times 11 \mu \mathrm{m})$. In experiments with the freshwater bivalves a mixture of the spherical green alga Chlorella vulgaris (2 to $5 \mu \mathrm{m}$ ) and latex beads $(1.1,2.1,7.9$ and $13.7 \mu \mathrm{m})$ were added to the ambient water.

Efficiencies of particle retention were assessed by the method of Møhlenberg and Riisgård (1978). Sam- ples of inhalant and exhalant water were taken from actively filtering, undisturbed animals by glass tubes placed immediately above the inhalant and exhalant apertures. The size distribution of particles in the water samples were then determined by means of an electronic particle counter, either an Elzone Counter model $80 \mathrm{xy}$ fitted with a 19 or $48 \mu \mathrm{m}$ orifice tube (all measurements carried out at Tjärnö) or a Coulter Counter model TA II with a $50 \mu \mathrm{m}$ tube (all other measurements). To freshwater samples were added $\mathrm{NaCl}$ to provide the required conductivity $(20 \%$ ) of the water without altering the particle size distribution The fractions of the various particle sizes retained by the filtering animals were calculated from the reduction in concentration in the water passing the animals. Above a certain particle size the percentage reduction was constant and high (mostly above $80 \%$ and often $100 \%$ ). Retention efficiency spectra were expressed as percentage reduction in retention with decreasing particle size relative to the maximum retention. Particle sizes were expressed by diameters of the equivalent spheric volumes recorded by the electronic particle counters.

To obtain absolute values for retention efficiencies the filter feeding animals must produce well defined exhalant currents. This was the case for most of the species studied, including the brachiopod Terebratulina retuso (Rudwick, 1970). The polychaete Sabella penicillus, however, produces diffuse currents that are passed through the crown from the outer convex to the inner concave side. In $S$. penicillus 'exhalant' water was collected by siphoning water through a funnel placed over the crown, the diameter of the funnel being a little larger than that of the crown. A sample of the 'inhalant' water was collected just below the crown. By this method a maximum reduction of 40 to $75 \%$ in concentration of optimally retained particles was obtained.

In some instances retention efficiency as determined by means of the Coulter Counter was compared with the retention of bacterioplankton present in the samples. Bacteria were counted on nuclepore filters by fluorescence microscopy according to Hobbie et al. (1977).

On all species studied, 4 to 15 measurements of retention efficiency were made on 1, 2 or more individuals. In the graphs showing the retention efficiency as a function of particle size the values represent means of 2 to 9 measurements. When more than 3 measurements were made, vertical lines indicate standard errors.

In some species filtration rate was determined from the rate (C) by which efficiently retained particles were cleared from suspensions by means of the equation: 


$$
\mathrm{C}=\mathrm{M} / \mathrm{t} \ln \mathrm{C}_{\mathrm{o}} / \mathrm{C}_{\mathrm{t}}
$$

where $\mathrm{M}=$ volume of suspension; $\mathrm{t}=$ time; $\mathrm{C}_{\mathrm{o}}$ and $\mathrm{C}_{\mathrm{t}}$ $=$ particle concentrations at time 0 and time t. Appropriate mixing of the water during the clearance-measurements was ensured by aeration.

Pressure drops across mucus filters were estimated from the equation:

$$
\Delta p=\frac{8 \pi \mu U_{\circ}}{b\left(1-2 \ln \tau+1 / 6 \tau^{2}\right)}
$$

where $\tau=\pi / b, d=$ diameter of mucus fibers; $b=$ center distance between neighbouring fibers of the nets; $\mu=$ viscosity; $U_{0}=$ flow velocity. The model is developed for filters consisting of parallel, equally spaced cylinders, but the pressure drops are little influenced by angular orientations of the cylinders in the plane normal to flow (Jørgensen, 1983).

\section{RESULTS AND DISCUSSION}

\section{Ciliary feeders}

Two types of metazoan feeding by means of ciliary bands can be distinguished. In the one type particles are collected below the water transporting band of cilia, downstream retention, e.g. sabellid polychaetes. In the other type particles are retained above the water transporting band, upstream retention, e.g. brachiopods and bivalves (Fig. 1).

\section{Sabellid polychaetes}

In Sabella penicillus and other sabellids the radiating filaments of the crown carry side branches, pinnules, equipped with laterofrontal tracts of cilia that produce the through currents. Ciliary tracts along the frontal, inner surface of the pinnules produce currents toward the base of the pinnules and further along the filaments toward the mouth region, centrally placed within the crown (Fig. 1 A). Fig. 2 B shows the efficiencies with which particles of various sizes suspended in the through currents are transferred into these surface currents. The data suggest an optimum particle size for retention of about $3 \mu \mathrm{m}$ in diameter, with little change in retention efficiency up to the largest particles included, about $8 \mu \mathrm{m}$. With decreasing particle size retention efficiency rapidly declined, to about $30 \%$ of the maximum at a particle size of about $1 \mu \mathrm{m}$ in apparent diameter.
Fig. 1. Types of ciliary filter feeding. Heavy arrows: through currents; light arrows: surface currents. (A) Sabellid polychaete, exhibiting downstream particle retention. Middle, frontal view of segment of gill crown tentacle; left, cross section of tentacle; right, cross section of pinnule, indicating path of particle from through current into surface current (modified from Nicol, 1931). (B) Brachiopod, upstream retention in a lophophorate. Middle, earliest functional lophophore stage; left, short segment of lophophore with filaments; right, cross section of filament, indicating path of particle from through current into surface current (modified from Rudwick, 1962, 1970). (C) Bivalve, upstream retention. Left, oblique frontal view on segment of four gill filaments; right, cross section of filament. Paths of particles from through currents into surface currents are indicated
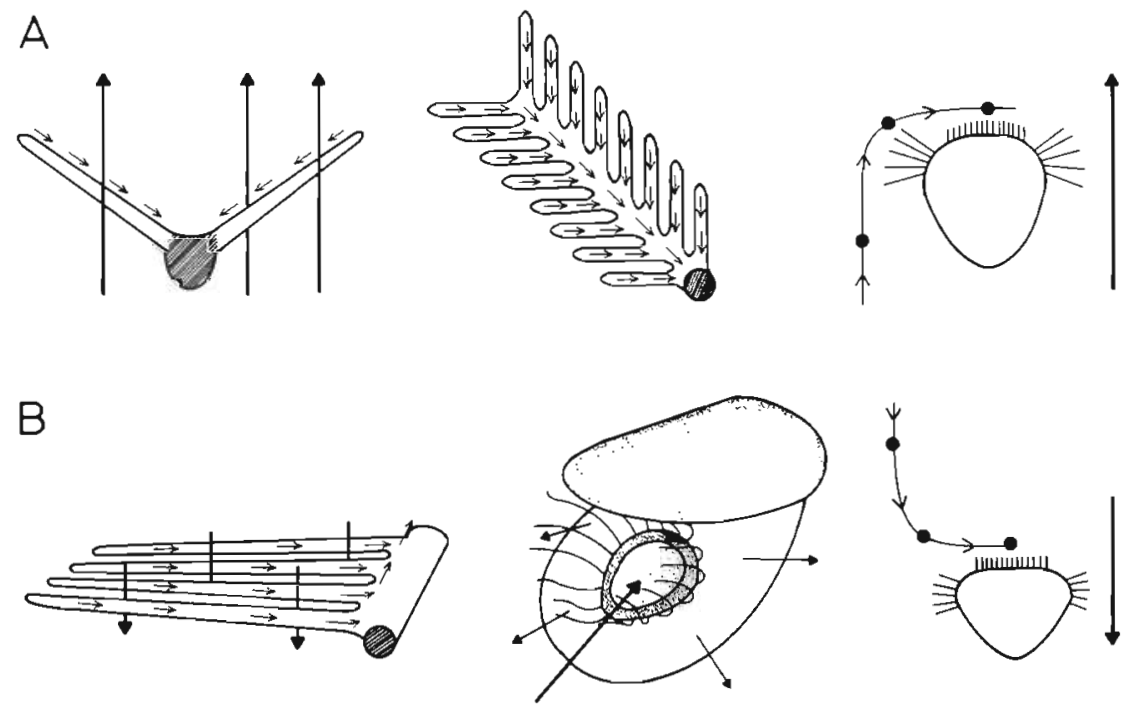

C
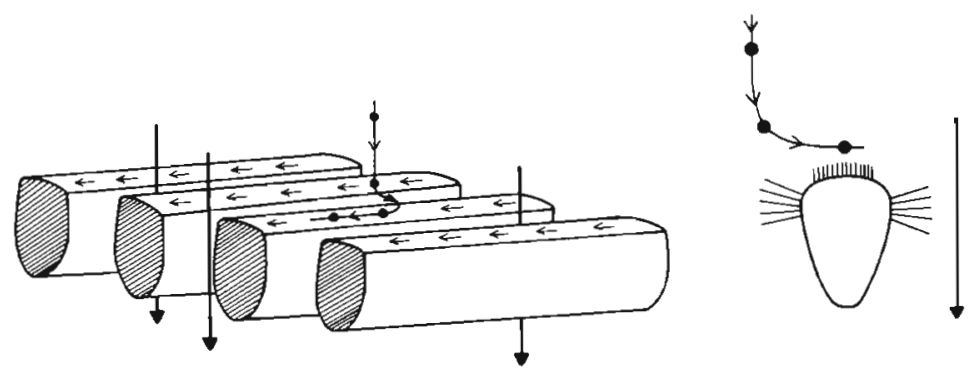
Brachiopods

The brachiopods are lophophorates, the lophophore being enclosed between a dorsal and a ventral calcareous valve. While the brachiopod lophophore may develop into a highly complex structure, all are composed of filaments that radiate from the variously looped or coiled brachium (arm). The rows of filaments divide the mantle cavity into an inhalant and an exhalant compartment, the through currents being produced by the metachronally beating bands of lateral cilia along the sides of the filaments. Suspended particles are transferred upstream to surface currents along the frontal surface of the filaments and further along the food groove of the lophophore axis to the mouth (Fig. 1 B). Fig. $2 \mathrm{~A}$ shows the efficiency with which particles of various sizes are retained by Terebratulina retuso. The efficiency of retention increased with particle size throughout the range-of sizes studied, from about 1 to $7 \mu \mathrm{m}$. A comparison with simultaneously sampled inhalant water showed that $67.8 \pm 10.2$ (SD) \% of $7 \mu \mathrm{m}$ particles were removed from the water during one passage of the lophophore.

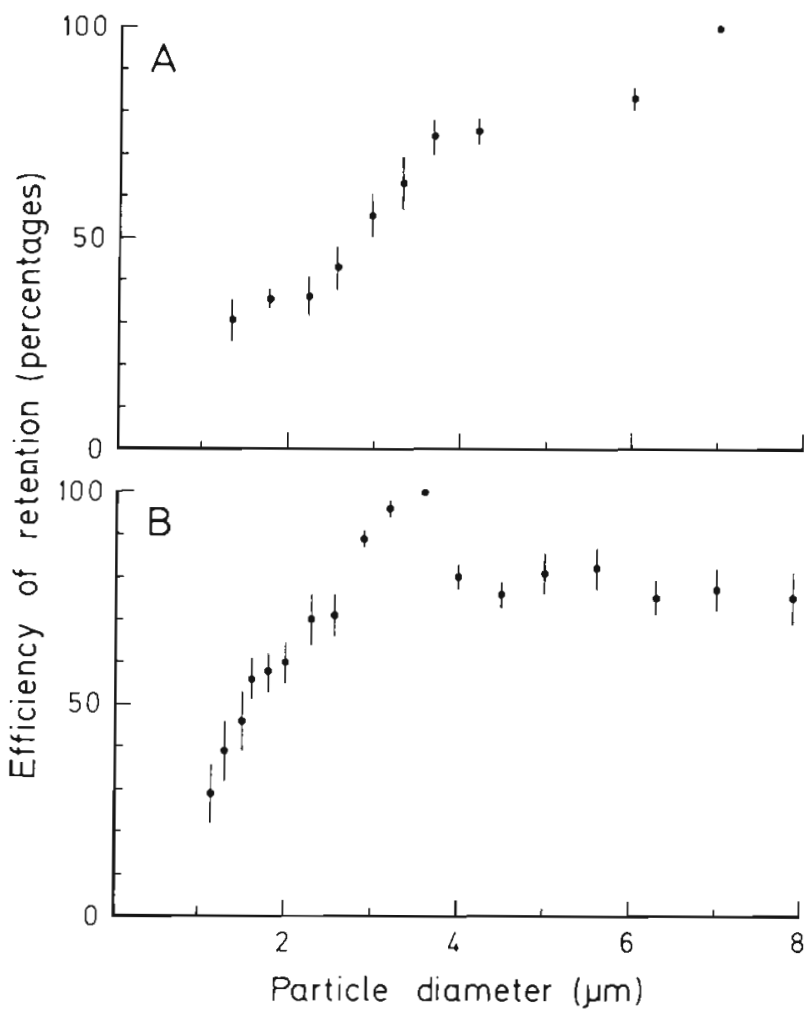

Fig. 2. Retention as a function of particle size in the brachiopod Terebratulina retuso (A) and the polychaete Sabella penicillus (B), determined with the Elzone Counter fitted with a $48 \mu \mathrm{m}$ orifice tube
Bivalves

The bivalves constitute the most studied group of filter feeding animals, but the mechanisms of water processing are still incompletely understood (Jørgensen, 1983). The feeding mechanism is of the upstream type and metachronally beating bands of lateral cilia along the sides of the gill filaments produce the interfilamentary through currents. Ciliary tracts along the frontal side of the filaments produce surface currents that gradually emerge into feeding currents terminating in the stomach. At the entrance to the interfilamentary spaces suspended particles move from the through currents into the surface currents (Fig. 1 C). Fig. 3 and 4 show the efficiency of particle retention in marine and freshwater bivalves. Particles began to pass through the gills in significant amounts at diameters that varied from about $5 \mu \mathrm{m}$ in Monia squama to $1 \mu \mathrm{m}$ in Dreissena polymorpha. In $M$. squama the lower threshold for particle retention was about $2 \mu \mathrm{m}$. In the other species the thresholds were below the particle range covered by the electronic particle counter used.

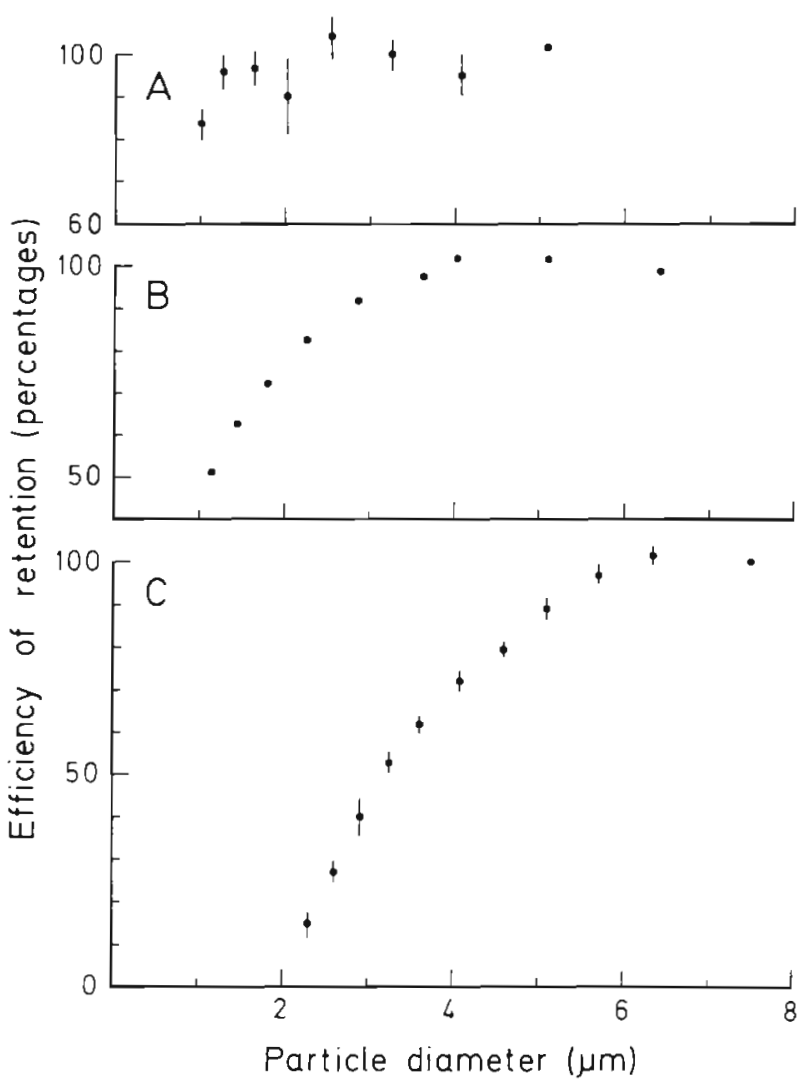

Fig. 3. Retention as a function of particle size in 3 marine bivalves: Petricola pholadiformis (A), Cardium glaucum (B) determined with Coulter Counter, and Monia squama (C) determined with Elzone Counter, $48 \mu \mathrm{m}$ orifice. C. glaucum values are means of 2 experiments 
The efficiency of particle retention in the bivalve gill has been correlated with structural features of the gills, especially the development of the laterofrontal cirri. Gill types with small or lacking laterofrontal cirri, e.g. in pectinids and Ostrea edulis, have been found less retentive than gills with well developed cirri (Møhlenberg and Riisgård, 1978). M. squama which lacks the cirri fits into this pattern. However, also gills with well developed laterofrontal cirri varied in retentiveness. Thus, Dreissena polymorpha efficiently retained $1.5 \mu \mathrm{m}$ latex particles which, measured with the same technique, passed the gill of Anodonta cygnea to about $60 \%$. A. cygnea was significantly leaky to particles of about $4 \mu \mathrm{m}$ in diameter. Unio pictarum was intermediate in efficiency of particle retention (Fig. 4 ; Table 1). The differences in retention between the species could not be correlated with differences in the development of the laterofrontal cirri, nor with the intercirral distances. Thus the mean center distance between cirri, measured on isolated gill fragments, was $2.3 \mu \mathrm{m}$ in $D$. polymorpha and $2.2 \mu \mathrm{m}$ in $A$. cygnea.

Clearance of algal suspensions and gill area were measured in four specimens of Dreissena polymorpha about $3 \mathrm{~cm}$ in length. The free velocity of the water current $\left(U_{0}\right)$ through the gill amounted to $0.2 \mathrm{~mm} \mathrm{~s}^{-1}$.

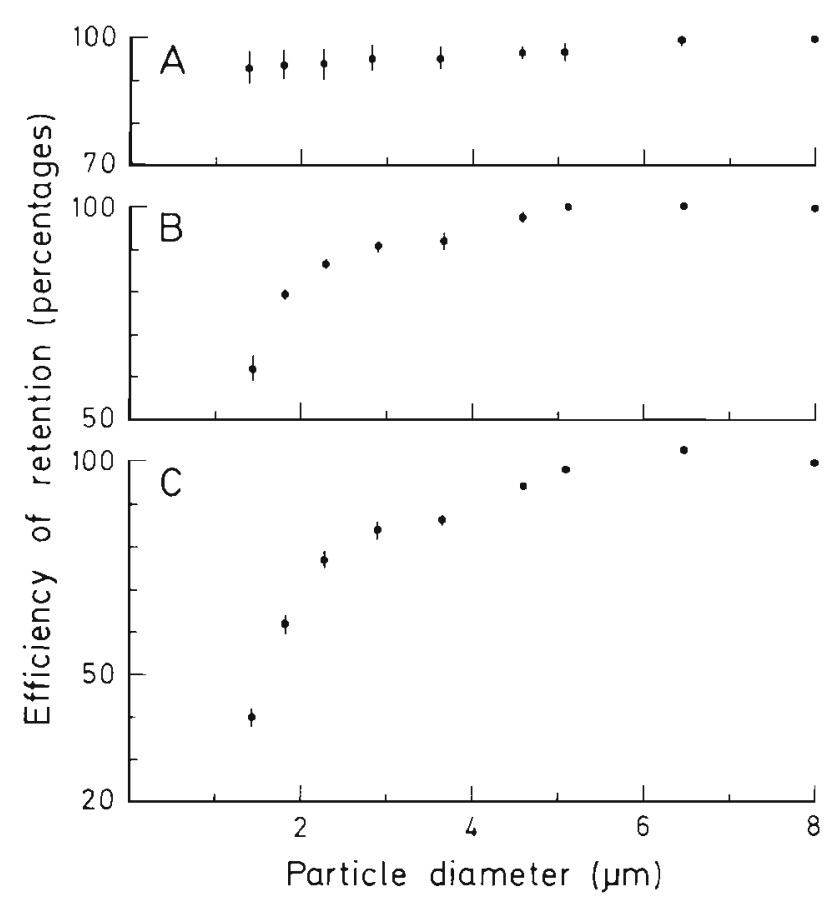

Fig. 4. Retention as a function of particle size in 3 freshwater bivalves: Dreissena polymorpha (A), Unio pictarum (B), and Anodonta cygnea (C), all determined with the Coulter Counter

Table 1. Characteristics of particle retention spectra as determined by electronic particle counting

\begin{tabular}{|c|c|c|c|c|c|}
\hline \multirow[t]{3}{*}{ Group, Species } & \multicolumn{4}{|c|}{ Particle diameters $(\mu \mathrm{m})$} & \multirow{3}{*}{$\begin{array}{c}\text { Diameter of tube } \\
\text { orifice }(\mu \mathrm{m})\end{array}$} \\
\hline & \multicolumn{2}{|c|}{$90 \%$ retention } & \multicolumn{2}{|c|}{$50 \%$ retention } & \\
\hline & C.C. & Elzone & C.C. & Elzone & \\
\hline \multicolumn{6}{|l|}{ Ciliary feeders } \\
\hline \multicolumn{6}{|l|}{ Polychaete } \\
\hline Sabella penicillus & & 3.0 & & 1.5 & 48 \\
\hline \multicolumn{6}{|l|}{ Brachiopod } \\
\hline Terebratulina retuso & & ca. 6.0 & & 2.7 & 48 \\
\hline \multicolumn{6}{|l|}{ Bivalves } \\
\hline Monia squama & & 5.2 & & 3.2 & 48 \\
\hline Cardium glaucum & 2.8 & & 1.1 & & \\
\hline Petricola pholadiformis & 2.2 & & & & \\
\hline Dreissena polymorpha & ca. 1.0 & & & & \\
\hline Unio pictarum & 2.6 & & & & \\
\hline Anodonta cygnea & 4.0 & & 1.6 & & \\
\hline \multicolumn{6}{|l|}{ Mucus-net feeders } \\
\hline \multicolumn{6}{|l|}{ Polychaete } \\
\hline Chaetopterus variopedatus & 1.2 & 1.7 & & ca. 0.5 & 19 \\
\hline \multicolumn{6}{|l|}{ Gastropod } \\
\hline Crepidula fornicata & 1.2 & & & & \\
\hline \multicolumn{6}{|l|}{ Ascidians } \\
\hline Ascidia virginia & 1.2 & 2.2 & & & \\
\hline A. obligua & 1.1 & 2.0 & & 1.1 & ) \\
\hline A. mentula & & 1.8 & & 0.9 & 19 \\
\hline Ciona intestinalis & 1.0 & 1.7 & & & \\
\hline Styela clava & 1.0 & & & & \\
\hline
\end{tabular}




\section{Mucus-net feeders}

Polychaetes

Chaetopterus variopedatus produces a leathery Ushaped tube which it ventilates by means of 3 fanshaped notopodia on the 14 th to 16 th segments. When feeding, the worm secretes a mucus net from the aliform notopodia of the 12 th segment. The feeding net is continuously produced, the posterior end being rolled up into a ball within the dorsal cupule, to be eaten at intervals of about $15 \mathrm{~min}$ (Fig. $5 \mathrm{~A}$ ). The ventilation current through the tube passes the net which thus filters the water. The filter is built of longitudinal and transverse mucus fibers forming a network of oblong rectangular meshes (Flood and Fiala-Médioni, 1982).

The critical particle size for efficient retention varied with the techniques used. The particle size corresponding to $90 \%$ retention was about 1.2 and $1.7 \mu \mathrm{m}$, when determined with the Coulter Counter and Elzone Counter. The latter indicated about $60 \%$ efficient retention of $0.5 \mu \mathrm{m}$ particles whereas the fluorescence microscopy indicated that only about $1 / 3$ of the large $(1 \mu \mathrm{m})$ bacteria were retained by the net (Fig. $6 \mathrm{~A}$; Table 2). These results should be compared with the dimensions of the meshes of the net as measured on electron microscopic preparations. Flood and FialaMédioni (1982) obtained a mesh size of $0.76 \pm 0.96$
Table 2. Comparison of particle retention efficiency as measured with fluorescence microscopy and electronic particle counting on the same samples of inhalant and exhalant water

\begin{tabular}{|c|c|c|c|}
\hline \multirow[t]{3}{*}{ Species } & \multicolumn{3}{|c|}{ Retention efficiency $(\%)$} \\
\hline & \multicolumn{2}{|c|}{ Bacteria } & \multirow{2}{*}{$\begin{array}{c}1 \mu \mathrm{m} \\
\text { particles } \\
\text { Coulter } \\
\text { Counter }\end{array}$} \\
\hline & $\begin{array}{c}\text { small } \\
\sim 0.5 \mu \mathrm{m}\end{array}$ & $\begin{array}{l}\text { large } \\
1-2 \mu \mathrm{m}\end{array}$ & \\
\hline Chaetopterus variopedatus & - & 35 & 81 \\
\hline Ciona intestinalis & ca. 20 & ca. 85 & 93 \\
\hline Asciaja virginia & ca. 10 & ca. 90 & 80 \\
\hline A. obliqua & ca. 0 & ca. 10 & 84 \\
\hline
\end{tabular}

Table 3 . Flow velocities and filter resistance: mucus nets

\begin{tabular}{|c|c|c|c|c|}
\hline Species & $\begin{array}{c}\text { Flow } \\
\text { velocity } \\
U_{o} \\
\left(\mathrm{~mm} \mathrm{~s}^{-1}\right)\end{array}$ & $\begin{array}{l}\text { Poro- } \\
\text { sity' } \\
b \\
(\mu \mathrm{m})\end{array}$ & $\mathrm{d} / \mathrm{b}$ & $\begin{array}{c}\Delta \mathrm{p} \\
(\mathrm{mm} \\
\left.\mathrm{H}_{2} \mathrm{O}\right)\end{array}$ \\
\hline \multicolumn{5}{|l|}{ Polychaete } \\
\hline Chaetopterus variopedatus & 3.0 & 1.7 & 0.02 & 0.7 \\
\hline Gastropod & & & & \\
\hline Crepidula fornicata & 0.8 & 1.8 & 0.02 & 0.2 \\
\hline Ascidian & & & & \\
\hline Ascidia mentula & 0.4 & 1.8 & 0.02 & 0.1 \\
\hline
\end{tabular}

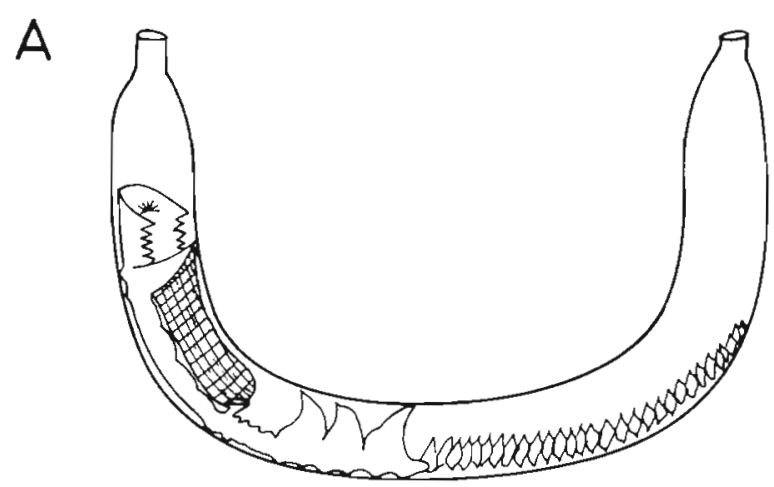

B

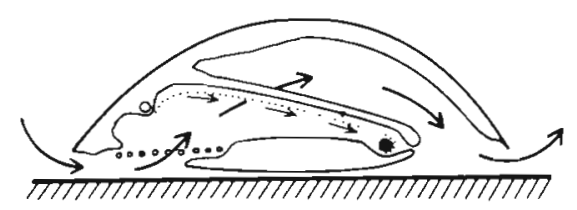

C

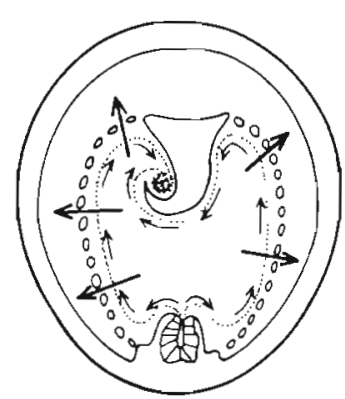

Fig. 5. Types of mucus-net filter feeding. Heavy arrows: through currents; light arrows: transport of mucus filters. (A) Chaetopterus variopedatus. Mucus net, suspended from pair of aliform notopodia and rolled up within the cupule, filters water current produced by 3 fan-shaped notopodia (after MacGinitie, 1939a). (B) Crepidula fornicata. Transverse section, indicating coarse mucus filter at entrance to mantle cavity and fine mucus filter continuously transported across gill and rolled up in the food groove on the dorsal side of the foot lafter Werner, 1959). (C) Ascidian. Transverse section, indicating through currents passing mucus filter and ostia perforating the pharynx wall. Mucus filters, produced ventrally in the endostyle, are continuously transported dorsally and rolled up within the dorsal lamina (after Werner, 1959) 
(SD) $\mu \mathrm{m} \times 0.46 \pm 0.12$ (S.D.) $\mu \mathrm{m}$. The longitudinal fibers were $0.1 \mu \mathrm{m}$ thick and the transverse $0.01 \mu \mathrm{m}$.

The rates at which Chaetopterus variopedatus cleared suspensions of algal cells were similar when measured for worms in their own tube or those transferred to glass tubes (Table 3 ). The dimensions of the net could be measured in the worms established in glass tubes, and the surface area calculated. From the clearance values and filter area the mean flow velocity through the net $\left(\mathrm{U}_{0}\right)$ was found to be about $3.0 \mathrm{~mm} \mathrm{~s}^{-1}$ (Table 3).

To calculate the pressure drop across the net we must know the mesh size and fiber thickness of the intact net. The particle retention spectrum suggests a mesh size of $\leqslant 1.7 \mu \mathrm{m}$ (Table 1). If the fibers are assumed to have shrunk corresponding to a $d / b$ ratio of 0.02 a $\Delta \mathrm{p}$ value of about $0.7 \mathrm{~mm} \mathrm{H}_{2} \mathrm{O}$ applies (Table 3 ).

The maximal pressure head a $26 \mathrm{mg}$ dry mass Chaetopterus variopedatus, accommodated in a $10 \mathrm{~cm}$ glass tube of $6.45 \mathrm{~mm}$ internal diameter, could produce was determined by placing the tube in the vertical position with the excurrent end of the tube elevated above the water surface. The difference in water levels outside and inside the tube was measured by a cathetometer to be about $8 \mathrm{~mm} \mathrm{H}_{2} \mathrm{O}$. The working pressure head thus amounted to about 1/10 the maximum.

\section{Gastropods}

Crepidula fornicata produces a water current through the mantle cavity by the activity of the lateral cilia of the gill filaments. The through current passes 2 mucus filters, a coarse filter at the entrance to the mantle cavity and a fine filter transported across the gill surface by means of the frontal cilia of the gill filaments (Fig. $5 \mathrm{~B}$ ). The coarse filter is built of longitudinal and transverse mucus fibers (Werner, 1953). The fine structure of the gill filter has not been studied. Using the Coulter Counter technique we found $C$. fornicata to retain particles completely down to about $2 \mu \mathrm{m}$, whereas $90 \%$ retention was measured at a value of $1.2 \mu \mathrm{m}$ in diameter (Fig. $6 \mathrm{~B}$ ). In a suspension of $1.9 \mu \mathrm{m}$ Chlorella virginica cells Williams (1978), also using the Coulter Counter, observed a pronounced drop in retention efficiency at a particle size corresponding to $1.4 \mu \mathrm{m}$. From Fig. 9, p. 5 of Williams (1978) it can be estimated that $1.4 \mu \mathrm{m}$ particles were retained with only one fourth the efficiency of the $2.2 \mu \mathrm{m}$ particles. The mean mesh size of the mucus net may thus be about $1.8 \mu \mathrm{m}$.

A specimen of Crepidula fornicata of $132 \mathrm{mg}$ dry body mass cleared $11.0 \pm 1.8$ (S.D.) ml of algal suspension per min. From the relation between shell length and gill area (Werner, 1951) the area of the gill filter

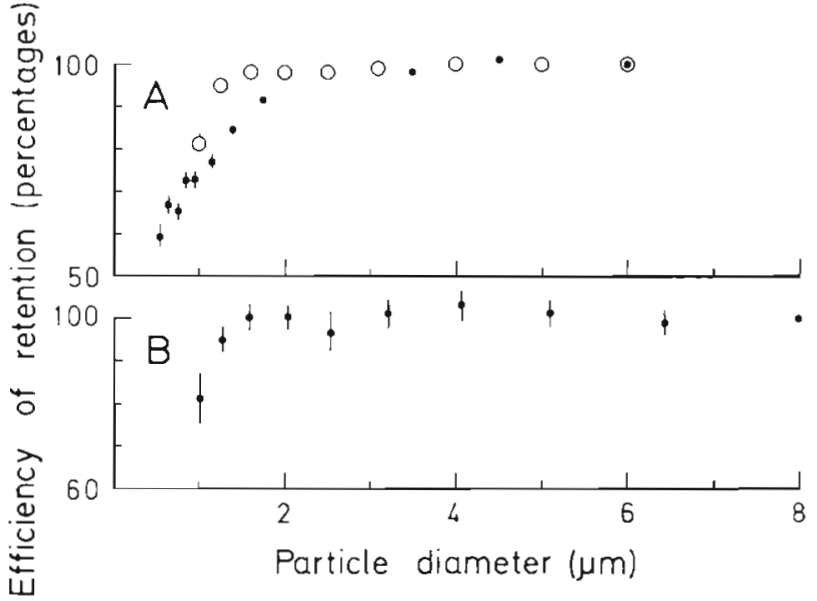

Fig. 6. Retention as a function of particle size in the polychaete Chaetopterus variopedatus (A) determined with Coulter Counter $(O)$ or Elzone Counter, $19 \mu \mathrm{m}$ orifice $(\bullet)$, and the gastropod Crepidula fornicata (B) determined with Coulter Counter

was estimated to be $242 \mathrm{~mm}^{2}$, providing a flow velocity through the filter of $0.8 \mathrm{~mm} \mathrm{~s}^{-1}$ (Table 3). To estimate the corresponding pressure drop across the filter the thickness of the mucus fibers should be known. A tentative $\mathrm{d} / \mathrm{b}$ value of 0.02 results in a $\Delta p$ of $0.2 \mathrm{~mm}$ $\mathrm{H}_{2} \mathrm{O}$ at a mesh size of $1.8 \mu \mathrm{m}$ (Table 3 ).

\section{Ascidians}

Ascidians feed by passing a current of water through the pharynx which communicates with the atrial cavity through numerous ciliated ostia in the pharynx wall. The ostial cilia produce the current which is filtered through a mucus net continuously secreted and transported across the pharynx wall, from the endostyle to the dorsal lamina (MacGinitie, 1939b; Fig. 5 C). The mucus net is built of longitudinal and transverse filaments that form rectangular meshes (Flood and FialaMédioni, 1981).

The net porosities found in a number of ascidians are shown in Fig. 7 and Table 1. Measurements using the Elzone Counter suggested that the nets became leaky to particles of equivalent diameters of about $2 \mu \mathrm{m}$, against about $1 \mu \mathrm{m}$ when using the Coulter Counter. Fluorescence microscopy indicated significant differences in retention efficiency between species, the Ascidia obliqua net being highly permeable to large bacteria which were retained with about $90 \%$ efficiency in Ciona intestinalis and Ascidia virginia (Table 2).

Flood and Fiala-Médioni (1981) obtained mesh sizes in the electron microscopic preparations that varied between species from 0.2 to $0.5 \mu \mathrm{m}$ in width and 0.5 to 


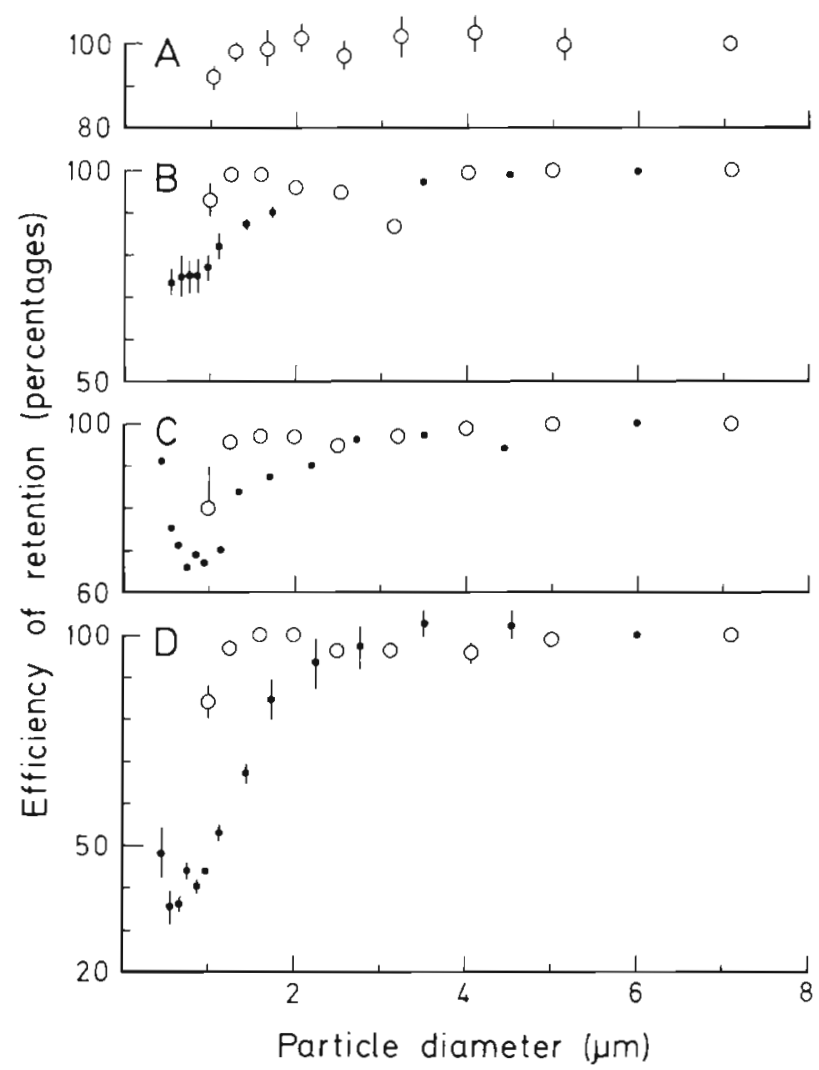

Fig. 7. Retention as a function of particle size in 4 ascidians: Styela clava (A), Ciona intestinalis (B), Ascidia virginia (C). and Ascidia obliqua (D), determined with Coulter Counter (O) or Elzone Counter, $19 \mu \mathrm{m}$ orifice (•)

$2.2 \mu \mathrm{m}$ in length, whereas the filaments were 10 to $40 \mathrm{~nm}$ thick, indicating some shrinkage of the mucus nets during preparation.

Specimens of Ascidia mentula, of $300 \mathrm{mg}$ dry soft tissue (total minus test) mass, cleared $119 \mathrm{ml} \mathrm{min}^{-1}$ of algal suspensions. The area of the pharynx wall was measured to be $54 \mathrm{~cm}^{2}$, providing a flow velocity through the mucus filter of $0.37 \mathrm{~mm} \mathrm{~s}^{-1}$. To estimate the pressure drop a $\mathrm{d} / \mathrm{b}$ value of 0.02 was chosen, which resulted in a $\Delta \mathrm{p}$ of about $0.1 \mathrm{~mm} \mathrm{H}_{2} \mathrm{O}$, at a mesh size of $1.8 \mu \mathrm{m}$ (Table 3 ).

\section{Efficiency of particle retention: comparison of methods}

The efficiencies of particle retention measured varied with the methods used. The threshold for efficient retention of particles was consistently found to be lower when estimated by means of the Coulter Counter fitted with a $50 \mu \mathrm{m}$ orifice tube as compared with the Elzone Counter fitted with a $19 \mu \mathrm{m}$ orifice tube (Table 1). The reason for this discrepancy is apparently that the Coulter Counter set-up operated at the lower limit of resolution where particle counts can be contaminated by electrical noise. Such noise did not interfere with the measurements made with the Elzone Counter. Another source of error may arise from the fact that electronic particle counters register particles by the equivalent volumes of non-conducting spheres. Natural waters contain varying amounts of colloidal particles of ill defined shapes and conductive properties. Such particles are recorded as particles of spherical volumes that are smaller than corresponding to the dimensions which determine how efficiently they are retained by the various types of filter feeders. When such particles are numerous in the water they will distort the retention spectra by tending to overestimate retention of small particles. If retention spectra are determined repeatedly in recirculated water the 'inflated' particles are removed faster than those more closely reflecting the equivalent volume, and the retention spectra should exhibit declining efficiencies at the lower end of the particle size range. An example is shown in Fig. 8. As can be seen, the retention efficiency of particles of an equivalent size of $0.45 \mu \mathrm{m}$ in diameter decreased with recirculation from about $60 \%$ to about $20 \%$. This discrepancy decreased with increasing particle size to practically disappear at $2.0 \mu \mathrm{m}$. Electronic particle counting therefore tended to overestimate the threshold size for efficient retention when these thesholds approached $1 \mu \mathrm{m}$, whereas thresholds at $2 \mu \mathrm{m}$ were probably reliably recorded. It therefore seems that the thresholds at about $2 \mu \mathrm{m}$, obtained with the Elzone Counter, reflects the largest mesh sizes in the mucus nets of Chaetopterus variopedatus as well as the ascidians. The lower end of the range of mesh sizes is less accurately determined, but

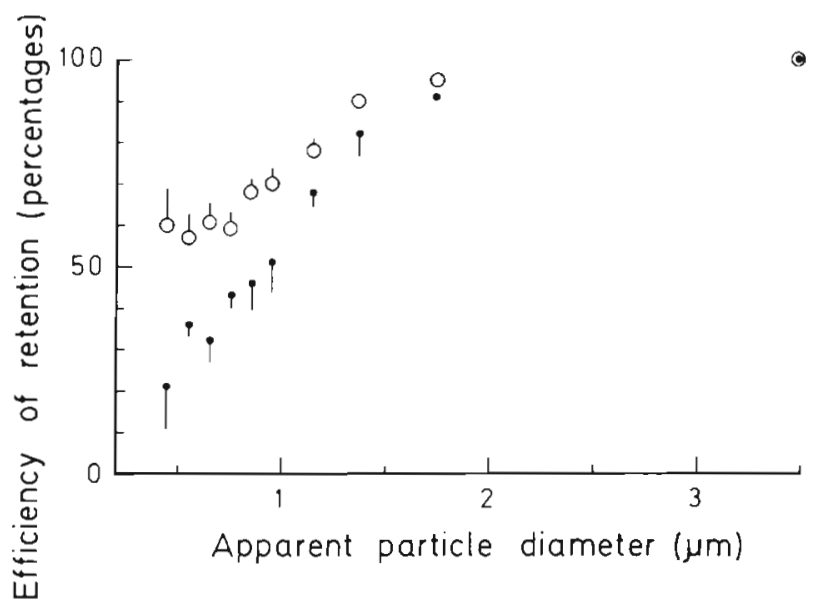

Fig. 8. Ascidia mentula. Apparent changes in efficiency of particle retention with time in a recirculating system. O mean values of 4 measurements from time zero to $42 \mathrm{~min}$; means of 3 measurements from time 53 to $82 \mathrm{~min}$, when the concentration of 3 to $4 \mu \mathrm{m}$ Isochrysis cells had been reduced to $21 \%$ of the initial concentration 
seems to approximate $0.5 \mu \mathrm{m}$ (Table 2). It is noteworthy that the counting of bacteria tended to indicate lower efficiencies of particle retention in the 1 to $2 \mu \mathrm{m}$ range than did the Coulter Counter recordings, e.g. C. variopedatus and Ascidia obliqua.

\section{Retention efficiency spectra}

Threshold values for particle retention varied with the type of filter feeders from about $6 \mu \mathrm{m}$ in diameter down to about $1 \mu \mathrm{m}$. In most ciliary feeders the lower limit for particle retention was found to be 1 to $2 \mu \mathrm{m}$. The bacterioplankton, ranging in size from about 1 to $0.3 \mu \mathrm{m}$, thus seems to be available to ciliary feeders only in exceptional instances. Wright et al. (1982) found that the gills of the mussel Geukensia demissa retained substantial fractions of the larger bacterioplankton from the through current.

Mucus-net feeding has resulted in more uniform filter characteristics than has ciliary feeding. The mucus nets consists of regularly spaced longitudinal and transverse mucus threads (Werner, 1959; Flood and Fiala-Médioni, 1981, 1982), and the dimensions of the meshes determine the efficiency of suspended particle retention. The threshold for efficient retention is about $2 \mu \mathrm{m}$ in both Chaetopterus variopedatus and several ascidians, and agrees with previous studies on ascidians (Randløv and Riisgård, 1979). The lower size limits for particle retention are not precisely known, but the data on retention of small and large components of the bacterioplankton suggest values around $1 \mu \mathrm{m}$.

\section{Comparison of ciliary feeding and mucus-net feeding}

Ciliary filter feeding is characterized by low pressure heads of less than $1 \mathrm{~mm} \mathrm{H}_{2} \mathrm{O}$ (Foster-Smith, 1976; Jørgensen, 1983) and is correlated with the low total pressures that ciliary water propulsion can accomplish, $5 \mathrm{~mm} \mathrm{H}_{2} \mathrm{O}$ or less. Present and previous data (Jørgensen, 1983) suggest that filter resistances to the water flow are similar in ciliary filter feeders and in the mucus-net feeders that propel the water by means of cilia. Mucus-net feeders that apply muscular force to produce the through currents may transport water at higher pressures, about $1 \mathrm{~mm} \mathrm{H}_{2} \mathrm{O}$ in Chaetopterus variopedatus. Transport pressures of $\geqslant 2 \mathrm{~mm} \mathrm{H}_{2} \mathrm{O}$ have been measured in the mucus-net feeding, tube-dwelling echiurid worm Urechis caupo, which propel water by muscular contractions of the body wall, the contractions passing along the body as peristaltic waves (Chapman, 1968). The higher pressure drop across the mucus filter in C. variopedatus than in Crepidula for- nicata and Ascidia mentula is correlated with a higher unrestricted flow velocity of the water (Table 3 ).

\section{Comparison of ciliary feeding in brachiopods and bivalves}

The unrestricted flow velocities through the brachiopod lophophore have been estimated to be $0.28 \mathrm{~mm} \mathrm{~s}^{-1}$ in Terebratalia transversa; $0.19 \mathrm{~mm} \mathrm{~s}^{-1}$ in Lagueus californianus; and $0.15 \mathrm{~mm} \mathrm{~s}^{-1}$ in Terebratulina unguicula (LaBarbera, 1981). In marine bivalves several times higher flow rates have been found, e.g. 1 to $2 \mathrm{~mm} \mathrm{~s}^{-1}$ in Mytilus edulis (Mohlenberg and Riisgård, 1979; Kiørboe et al., 1980; Jørgensen, 1983). This difference in flow velocities is correlated with relatively larger areas of lophophores than of gills. In $M$. edulis the gill area amounted to about $25 \mathrm{~cm}^{2} \mathrm{~g}^{-1}$ dry mass of soft tissues (Møhlenberg and Riisgård, 1979). In $T$. septentrionalis the area can be estimated to be about $75 \mathrm{~cm}^{2} \mathrm{~g}^{-1}$ dry mass (Hammen, 1977; LaBarbera, 1981). The efficiency of particle retention in brachiopods has been determined in only 1 species, Terebratulina retuso, which exhibited a particle retention spectrum comparable to those exhibited by non-retentive bivalves, such as pectinids (Møhlenberg and Riisgård, 1978) and Monia squama.

Brachiopods and bivalves show striking structural similarities. It is therefore of interest to explore to what extent such similarities are reflected in the water processing mechanisms. Both brachiopods and bivalves pump water through a mantle cavity by means of bands of lateral cilia along the filaments. In both groups suspended particles are transferred to the surface currents of the filaments, and further along food grooves to the mouth (Rudwick, 1970; Jørgensen, $1981 \mathrm{a}, \mathrm{b})$. Two main systems of currents can thus be distinguished within the mantle cavity of both groups, a system of through currents and a system of surface currents. The through currents are produced by the metachronal waves of the lateral cilia. The properties of the waves have not been studied in brachiopods, but they may be comparable to those of the metachronal waves produced by the lateral cilia of the bivalve gill filaments. In bivalves the constant through currents originate from oscillatory currents produced by the oscillatory movements of the enveloping surface of the metachronally beating bands of lateral cilia (Jørgensen, 1982). Presumably, such oscillatory components of the interfilamentary currents also constitute parts of the patterns of mantle currents in brachiopods.

LaBarbera (1981) found that the through current in brachiopods is laminar. Streams of dyed water as narrow as about $300 \mu \mathrm{m}$ did not visibly broaden from their entry into the mantle cavity till they emerged from the 
exhalant gape. This implies that the surface currents and the oscillatory components of the interfilamentary currents are laminar, and that no mixing of water occurs between the through currents and the surface currents. Suspended particles must therefore move perpendicularly to the streamlines in order to pass from the system of through currents into the surface currents. Such movements are compatible with the fluid mechanical hypothesis proposed for particle retention in the bivalve gill (Jørgensen, 1981a, 1982).

Acknowledgements. Thanks are due to the Institute of Ecology and Genetics, University of Århus, for provision of room and facilities at the Biological Station, Rønbjerg, and to Professor T Fenchel, Mrs. A. Sølling and Mr. P. Andersen for advise and help with the fluorescence microscopy. We thank Dr. J.-O. Strömberg, Kristineberg Marine Biological Station, Sweden, for the supply of Chaetopterus variopedatus, and Dr. U. Barmstedt at the Marine Biological Laboratory, Tjärnö, for careful instruction in the use of the Elzone Counter.

\section{LITERATURE CITED}

Bonar, D. B. (1972). Feeding and tube construction in Chona mollis Bush (Polychaeta, Sabellidae). J. exp. mar Biol. Ecol. 9: 1-18

Chapman, G. (1968). The hydraulic system of Urechis caupo Fisher \& MacGinitie. J. exp. Biol. 49: 657-667

Chuang, S. H. (1956). The ciliary feeding mechanisms of Lingula unguis (L.) (Brachiopoda). Proc. zool. Soc. Lond. 127: $167-189$

Fenchel, T. (1980). Suspension feeding in ciliated protozoa: Structure and function of feeding organelles. Arch. Protistenk. 123: 239-260

Flood, P. R., Fiala-Mêdioni, A. (1981). Ultrastructure and histochemistry of the food trapping mucous film in benthic filter-feeders (Ascidians). Acta. zool. Stockh. 62: 53-65

Flood, P. R., Fiala-Médioni, A. (1982). Structure of the mucous feeding filter of Chaetopterus variopedatus (Polychaeta). Mar Biol. 72: 27-33

Foster-Smith, R. L. (1976). Pressures generated by the pumping mechanism of some ciliary filter-feeders. J. exp. mar. Biol. Ecol. 25: 199-206

Hammen, C. S. (1977). Brachiopod metabolism and enzymes Am. Zool. 17: 141-147

Hobbie, J. E., Daley, R. J., Jasper, S. (1977). Use of nuclepore filters for counting bacteria by fluorescence microscopy. App. environ. Microbiol. 33: 1225-1228

Jørgensen, C. B. (1981a). A hydromechanical principle for particle retention in Mytilus edulis and other ciliary suspension feeders. Mar. Biol. 61: 277-282

Jørgensen, C. B. (1981b). Feeding and cleaning mechanisms in the suspension feeding bivalve Mytilus edulis. Mar Biol. 65: 159-163

Jørgensen, C. B. (1982). Fluid mechanics of the mussel gill: the lateral cilia. Mar. Biol. 70: 275-281
Jorgensen, C. B. (1983). Fluid mechanical aspects of suspension feeding. Mar. Ecol. Prog. Ser 11. 89-103

Kiørboe, T., Møhlenberg, F. (1981). Particle selection in suspension-feeding bivalves. Mar. Ecol. Prog. Ser. 5: 291-296

Kiørboe, T., Møhlenberg, F., Nøhr, O. (1980). Feeding, particle selection, and carbon absorption in Mytilus edulis in different mixtures of algae and resuspended bottom material. Ophelia 19: 193-205

Koehl, M. A. R., Strickler, J. R. (1981). Copepod feeding currents: food capture at low Reynolds number. Limnol. Oceanogr. 26: 1062-1073

LaBarbera, M. (1981). Water flow patterns in and around three species of articulate brachiopods. J. exp. mar. Biol. Ecol. 55: $185-206$

Lewis, D. B. (1968). Feeding and tube-building in the Fabricinae (Annelida, Polychaeta). Proc. Linn. Soc. Lond. 179: $37-49$

MacGinitie, G. E. (1939a). The method of feeding of Chaetopterus. Biol. Bull. mar. biol. Lab., Woods Hole 77 : 115-118

MacGinitie, G. E. (1939b). The method of feeding of tunicates. Biol. Bull. mar. biol. Lab., Woods Hole 77: 443-447

Mohlenberg, F., Riisgård, H. U. (1978). Efficiency of particle retention in 13 species of suspension feeding bivalves. Ophelia 17: 239-246

Mahlenberg, F., Riisgård, H. U. (1979). Filtration rate, using a new indirect technique, in thirteen species of suspensionfeeding bivalves. Mar. Biol. 54: 143-148

Nicol, E. A. T. (1931). The feeding mechanism, formation of the tube, and physiology of digestion in Sabella pavonina. Trans. R. Soc. Edinb. 56: 537-599

Randløv, A., Riisgård, H. U. (1979). Efficiency of particle retention and filtration rate in four species of ascidians. Mar. Ecol. Prog. Ser. 1: 55-59

Rudwick, M. J. S. (1962). Filter-feeding mechanisms in some brachiopods from New Zealand. J. Linn. Soc. 44: 592-615

Rudwick, M. J. S. (1970). Living and fossil brachiopods. Hutchinson, London

Strathmann, R. R. (1971). The feeding behavior of planktotrophic echinoderm larvae: mechanisms, regulation, and rates of suspension-feeding. J. exp. mar. Biol. Ecol, 6: $109-160$

Strathmann, R. (1973). Function of laeral cilia in suspension feeding of lophophorates (Brachiopoda, Phoronida, Ectoprocta). Mar. Biol. 23: 129-136

Werner, B. (1951). Über die Bedeutung der Wasserstromerzeugung und Wasserstromfiltration für die Nahrungsaufnahme der ortsgebundenen Meeresschnecke Crepidula fornicata L. (Gastropoda Prosobranchia). Zool. Anz. 146: $97-113$

Werner, B. (1953). Uber den Nahrungserwerb der Calyptraeidae (Gastropoda Prosobranchia). Helgoländer wiss. Meeresunters. 4: 260-313

Werner, B. (1959). Das Prinzip des endlosen Schleimfilters beim Nahrungserwerb wirbelloser Meerestiere. Int. Revue ges. Hydrobiol. 44: 181-216

Williams, L. G. (1978). Influence of algal cell volume and algal culture filtrates on suspension feeding behavior of the gastropod Crepidula fornicata (Prosobranchia). Ph. D. Dissertation, University of Delaware

Wright, R. T., Coffin, R. B., Ersing, C. P., Pearson, D. (1982). Field and Jaboratory measurements of bivalve filtration of natural marine bacterioplankton. Limnol. Oceanogr 27 : $91-98$ 